\title{
Impact of Immunochemotherapy-Related Hepatic Toxicity on the Outcome of HCV-Positive Diffuse Large B-Cell Lymphoma Patients
}

\author{
Fouad Abu-Taleb, ${ }^{1}$ Rasha Haggag, ${ }^{1}$ Yasser Elnaggar, ${ }^{2}$ and Ahmed Embaby ${ }^{2}$ \\ ${ }^{1}$ Department of Medical Oncology, Faculty of Medicine, Zagazig University, Sharkia 44519, Egypt \\ ${ }^{2}$ Department of Internal Medicine, Faculty of Medicine, Zagazig University, Sharkia 44519, Egypt \\ Correspondence should be addressed to Rasha Haggag; dr_rmmh@yahoo.com
}

Received 16 August 2014; Revised 4 November 2014; Accepted 4 November 2014; Published 30 November 2014

Academic Editor: Takahiro Yamauchi

Copyright (C) 2014 Fouad Abu-Taleb et al. This is an open access article distributed under the Creative Commons Attribution License, which permits unrestricted use, distribution, and reproduction in any medium, provided the original work is properly cited.

\begin{abstract}
We conducted this prospective study which included 28 de novo CD20-positive DLBCL patients to assess the clinical outcome, treatment response, and hepatic toxicity in DLBCL patients who received rituximab-CHOP as a first line treatment in relation to HCV infection status. We included 7 patients with positive HCV infection (group A) and 21 patients with negative HCV infection (group B). HCV infection was not a significant risk factor for prognosis (1-year event-free survival rates, $71.4 \%$ versus $81 \%, P=0.53$; overall survival rates, $85.7 \%$ versus $90.5 \%, P=0.72$, for groups A and $\mathrm{B}$, resp.). CR rate was $71.4 \%$ (5/7) in group A and $76.2 \%(16 / 21)$ in group B $(P=0.8)$. Of the 7 patients who were HCV positive, $2(28.6 \%)$ had enzyme flare (grade 2$)$, compared with 1 of the $21(4.8 \%)$ patients who were HCV negative $(P=0.15)$. Two $(28.6 \%)$ of the 7 positive HCV infection patients had viral reactivation ( $\geq 1 \log _{10} \mathrm{IU} / \mathrm{mL}$ increase in the viral load). No patient required discontinuation of immunochemotherapy owing to hepatotoxicity in either group. In conclusion, HCV infection might not influence the clinical course in DLBCL patients who receive rituximab-CHOP. Close monitoring of hepatic function and viral load is recommended.
\end{abstract}

\section{Introduction}

The role of HCV infection in lymphomagenesis is related to several mechanisms such as the sustained antigenic stimulation of the B-cell compartment, viral lymphotropism, and viral proteins, chromosomal aberrations, cytokines, and microRNAs [1].

For decades, the combination of cyclophosphamide, doxorubicin, vincristine, and prednisone (CHOP) was the standard regimen for patients with DLBCL, curing about $30 \%$ of the patients; no advantage was observed with more intensive combinations [2]. However, the addition of rituximab, a chimeric monoclonal antibody which targets CD20positive lymphocytes, to the $\mathrm{CHOP}$ regimen induces a significantly higher complete-response rate and increased eventfree and overall survival in patients with DLBCL. Therefore, rituximab-combined $\mathrm{CHOP}$ regimen (R-CHOP) as immunochemotherapy is now considered to be the standard treatment for patients with DLBCL [3].

Although hepatitis B virus (HBV) reactivation is a welldocumented and potentially fatal complication that occurs frequently after introduction of rituximab, data on $\mathrm{HCV}$ reactivation or liver dysfunction after chemotherapy for NHL especially with rituximab-containing regimen are controversial [4].

In this report, we compare the clinical characteristics, treatment-related toxicity, and outcome of our patients in relation to $\mathrm{HCV}$ status.

\section{Patients and Methods}

2.1. Eligibility. This prospective study included twenty-eight patients with pathological proof of CD20-positive DLBCL. On the basis of statistical theory we collected up to 7 patients 
with HCV-positive infection (group A) and 21 patients with HCV-negative infection (group B). All of them had detectable HCV RNA before treatment and none had received previous treatment for HCV infection at Medical Oncology Department, Zagazig University Hospitals, during the period from February 2013 to October 2014.

Patients were excluded if they were positive for hepatitis B surface antigen (HBsAg), hepatitis B core antibody (anti$\mathrm{HBc}$ ), or human immunodeficiency virus. Patients with primary central nervous system lymphoma and primary testicular lymphoma were also excluded.

All eligible patients were treated with rituximab-CHOP, on day 1 of a 21-day cycle with intravenous rituximab $375 \mathrm{mg} /$ $\mathrm{m}^{2}$; cyclophosphamide, $750 \mathrm{mg} / \mathrm{m}^{2}$; doxorubicin, $50 \mathrm{mg} / \mathrm{m}^{2}$; vincristine, $1.4 \mathrm{mg} / \mathrm{m}^{2}$ (maximum of $2.0 \mathrm{mg}$ ); and prednisone, $100 \mathrm{mg}$ by mouth daily for 5 days. Patients with stage I, stage IE, or nonbulky stage II were treated with three cycles of CHT followed by involved field radiotherapy beginning 3 weeks after the third cycle of chemotherapy. Patients with more advanced disease received a minimum of six cycles of chemotherapy or two cycles beyond documentation of complete remission. Treatment was stopped if there was no response, if the lymphoma progressed, or if severe adverse effect developed.

2.2. Liver Function Tests and HCV Viral Markers. In all patients enrolled, the pretreatment levels of alanine aminotransferase (ALT) as well as its highest levels during treatment and its level at the last follow-up after completing treatment were collected.

In HCV-positive patients, HCV RNA in serum was done at the beginning and at the end of treatment as well as to patients who developed enzyme flare during the course of treatment. It was quantified using a commercially available polymerase chain reaction method (COBAS TaqMan HCV Test; Roche Molecular Systems, Branchburg, NJ) with a quantification range from 43 to $69,000,000 \mathrm{IU} / \mathrm{mL}$ and patients with detectable HCV RNA in serum were considered to have proven $\mathrm{HCV}$ infection [5].

Acute exacerbation of chronic HCV infection (enzyme flare) was defined as a 3-fold or greater increase in serum ALT level above the upper limits of normal (ULN $=40 \mathrm{IU} / \mathrm{L})$, in the absence of use of hepatotoxic drugs (other than chemotherapeutics), or other systemic infections besides HCV.

$\mathrm{HCV}$ reactivation (viral flare) was defined as an increase in HCV viral load of at least $1 \log _{10} \mathrm{IU} / \mathrm{mL}$ over baseline following chemotherapy or immunosuppressive therapy, as chronically infected patients have stable HCV RNA levels that may vary by $0.5 \log _{10} \mathrm{IU} / \mathrm{mL}$.

\section{Toxicity Evaluation}

Toxicities were assessed according to the National Cancer Institute-Common Terminology Criteria for Adverse Events (CTCAE) Version 4.0.32010.

\section{Follow-Up}

At the end of therapy, clinical examination and laboratory investigations (including LFTs) were done every 3 months and radiological evaluation by computed tomography scan was done every 6 months till the end of the study.

This study was approved by the Institutional Review Board of Zagazig University with all of the provisions of the Declaration of Helsinki with informed consent from all patients.

\section{Statistical Analysis}

The collected data were presented, summarized, tabulated, and analyzed by using computerized software statistical packages (SPSS version 20). Mean \pm standard deviation with median and range when appropriate described quantitative data. Numbers with percentages described qualitative data. Chi-square test $\left(\chi^{2}\right)$ and Fisher exact test were used to compare proportions while independent sample $t$-test was used to compare means between both groups and paired sample $t$-test to compare the changes in viral load before and after treatment $(P$ value $\leq 0.05$ was considered to be statistically significant at $95 \%$ confidence interval).

5.1. Survival Analysis. Kaplan and Meier method was used to estimate overall and event-free survival and log rank test compared survival curves ( $P$ value was considered significant at $\leq 0.05$ levels). Overall survival (OS) was calculated as the interval between the date of diagnosis till date of death or date of last follow-up. Event-free survival (EFS) was calculated from the treatment initiation date till the date of documented disease progression, relapse, or the end date of the study.

\section{Results}

6.1. Patient Characteristics. A total of 28 patients with CD20positive DLBCL were enrolled in our study. Pretreatment characteristics are shown in Table 1.

The study included 18 males (64.3\%) and 10 females (35.7\%) with a ratio of $1.8: 1$ and the median age of the patients at presentation was 49 years (range: $19-73$ years). Seven (25\%) out of the 28 patients were positive for HCV antibody and had detectable HCV RNA before chemotherapy.

At presentation, $57.1 \%$ of patients (16/28 of patients) had B symptoms and $39.3 \%$ of patients (11/28 of patients) presented with splenomegaly while $46.4 \%$ of patients (13/28 of patients) had hepatomegaly.

In addition, $10.7 \%$ of patients (3/28 of patients) had splenic involvement while only $3.6 \%$ of patients $(1 / 28$ of patients) had hepatic involvement at presentation.

Extranodal involvement was found in $25 \%$ of patients (7/28 patients): four of them presented with single extranodal site while three presented with 2 extranodal sites.

Elevated serum level of LDH was found in 67.9\% of patients (19/28 patients) and $64.3 \%$ of patients $(18 / 28$ 
TABLE 1: The baseline characteristics of patients of both groups.

\begin{tabular}{|c|c|c|c|}
\hline Variable & $\begin{array}{l}\text { HCV positive } \\
\text { (group A; } n=7 \text { ) } \\
\text { Number }(\%)\end{array}$ & $\begin{array}{l}\text { HCV negative } \\
\text { (group B; } n=21 \text { ) } \\
\text { Number }(\%)\end{array}$ & $P$ value \\
\hline \multicolumn{4}{|l|}{ Age (years) } \\
\hline Median (range) & $49(34-66)$ & $49(19-73)$ & 0.58 \\
\hline \multicolumn{4}{|l|}{ Gender } \\
\hline (i) Male & $5(71.4 \%)$ & $13(61.9 \%)$ & \multirow{2}{*}{0.65} \\
\hline (ii) Female & $2(28.6 \%)$ & $8(38.1 \%)$ & \\
\hline B symptoms & $5(71.4 \%)$ & $11(52.4 \%)$ & 0.66 \\
\hline \multicolumn{4}{|l|}{ Performance status } \\
\hline (i) $0-1$ & $6(85.7 \%)$ & $12(57.1 \%)$ & \multirow{2}{*}{0.36} \\
\hline (ii) $>1$ & $1(14.3 \%)$ & $9(42.9 \%)$ & \\
\hline Elevated LDH & $5(71.4 \%)$ & $14(66.7 \%)$ & 0.82 \\
\hline \multicolumn{4}{|l|}{ DLBCL stage } \\
\hline (i) I & $0(0 \%)$ & $3(14.3 \%)$ & \multirow{4}{*}{0.67} \\
\hline (ii) II & $3(42.9 \%)$ & $9(42.9 \%)$ & \\
\hline (iii) III & $3(42.9 \%)$ & $6(28.5 \%)$ & \\
\hline (iv) IV & $1(14.2 \%)$ & $3(14.3 \%)$ & \\
\hline BM involvement & $1(14.3 \%)$ & $1(4.8 \%)$ & 0.44 \\
\hline Splenomegaly (only) & $3(42.9 \%)$ & $8(38.1 \%)$ & 0.82 \\
\hline Splenic involvement & $3(42.9 \%)$ & $0(0 \%)$ & $0.01^{*}$ \\
\hline Hepatomegaly (only) & $3(42.9 \%)$ & $10(47.6 \%)$ & 0.82 \\
\hline Hepatic involvement & $0(0 \%)$ & $1(4.8 \%)$ & 0.56 \\
\hline \multicolumn{4}{|l|}{ Extranodal sites } \\
\hline (i) 1 & $0(0 \%)$ & $4(14.3 \%)$ & \multirow[t]{2}{*}{0.64} \\
\hline (ii) 2 & $1(14.3 \%)$ & $2(9.5 \%)$ & \\
\hline \multicolumn{4}{|l|}{ R.IPI } \\
\hline (i) Very good & $0(0 \%)$ & $7(33.3 \%)$ & \multirow{3}{*}{0.19} \\
\hline (ii) Good & $6(85.7 \%)$ & $11(52.4 \%)$ & \\
\hline (iii) Poor & $1(14.3 \%)$ & $3(14.3 \%)$ & \\
\hline
\end{tabular}

${ }^{*}$ means significant $(P<0.05)$.

patients) had a PS $\leq 1$, while $46.4 \%$ of patients (13/28 patients) presented with advanced stages (III and IV).

Regarding the R-IPI, $25 \%$ of patients (7/28 patients) had very good score while $60.7 \%$ of patients (17/28 patients) had good score and only $14.3 \%$ of patients ( $4 / 28$ patients) had poor score.

There was a significant difference as regards the splenic involvement as $42.9 \%$ of patients in group A (3/7 patients) versus no patients in group $B$ presented with splenic involvement $(P=0.01)$.

However, there was no significant difference between both groups as regards the age, gender, B symptoms, PS, stage, pretreatment LDH, extranodal sites, splenomegaly, hepatomegaly, hepatic involvement, and bone marrow involvement.

The baseline pretreatment laboratory characteristics of both groups; there was a significant difference as regards the
TABLE 2: The baseline laboratory values of both groups.

\begin{tabular}{lccc}
\hline Variable & $\begin{array}{c}\text { HCV positive } \\
\text { (group A) } \\
\text { Mean } \pm \text { standard } \\
\text { deviation }\end{array}$ & $\begin{array}{c}\text { HCV negative } \\
\text { (group B) } \\
\text { Mean } \pm \text { standard } \\
\text { deviation }\end{array}$ & $P$ value \\
\hline $\begin{array}{l}\text { WBC } \\
\left(\text { cells/mm } / \mathrm{mm}^{3}\right)\end{array}$ & $6.3 \pm 2.1$ & $6.2 \pm 2.7$ & 0.95 \\
$\begin{array}{l}\text { Hemoglobin } \\
(\text { g/dL) }\end{array}$ & $12.6 \pm 0.8$ & $11.2 \pm 1.5$ & $0.03^{*}$ \\
$\begin{array}{l}\text { Platelets } \\
\left(\times 10^{3} / \mathrm{mm}^{3}\right)\end{array}$ & $276.9 \pm 115.4$ & $276.7 \pm 104.3$ & 0.99 \\
$\begin{array}{l}\text { Bilirubin } \\
(\mathrm{mg} / \mathrm{dL})\end{array}$ & $0.9 \pm 0.5$ & $0.8 \pm 0.2$ & 0.48 \\
$\begin{array}{l}\text { Albumin } \\
(\mathrm{mg} / \mathrm{dL})\end{array}$ & $4.0 \pm 0.5$ & $4.1 \pm 0.4$ & 0.49 \\
$\begin{array}{l}\text { ALT }(\mathrm{IU} / \mathrm{L}) \\
\text { AST }(\mathrm{IU} / \mathrm{L})\end{array}$ & $55.0 \pm 30$ & $37.1 \pm 15$ & 0.14 \\
$\begin{array}{l}\text { INR } \\
\text { Creatinine } \\
(\mathrm{mg} / \mathrm{dL})\end{array}$ & $56.3 \pm 30$ & $40.6 \pm 17$ & 0.1 \\
\hline${ }^{*}$ means significant $(P<0.05)$. & $1.1 \pm 0.2$ & 0.23 \\
& $1.2 \pm 0.3$ & $0.8 \pm 0.3$ & 0.51 \\
\hline
\end{tabular}

baseline hemoglobin level $(P=0.03)$. However, no significant differences were found between both groups regarding the pretreatment WBCs, platelets, serum bilirubin, ALT, AST, INR, albumin, and serum creatinine (Table 2).

\section{Response to Chemotherapy}

Responders (who achieved CR) were $71.4 \%$ of group A (5/7 patients) compared to $76.2 \%$ of group $B(16 / 21$ patients), while nonresponders (who achieved PR, PD, or SD) were $28.6 \%$ of group A (2/7 patients) compared to $23.8 \%$ of group B (5/21 patients). However, no significant difference was found as regards the response to chemotherapy between the two groups $(P=0.8)$.

7.1. Overall Survival. After a median follow-up period of 18.1 months (range, 6.1-20.1 months), $10.7 \%$ of patients died (3/28 patients); the 1st was HCV-negative and achieved PR and then died following coronary bypass surgery after 7 months of diagnosis, the 2nd patient was HCV positive and achieved PR and then died when shifted to a salvage therapy due to progression of lymphoma and development of hepatic failure after 8 months of diagnosis, and the third patient was HCVnegative and achieved PR and died due to disease progression at 11 months of diagnosis.

The 1-year overall survival rate was $89.3 \%$ with a mean of $18.7 \pm 0.69$ months (95\% CI; 17.4-20.1 months); however, the median OS was not reached.

The 1-year event-free survival rate was $78.6 \%$ with a mean of $17.7 \pm 0.87$ months (95\% CI; 15.9-19.3 months) while the median EFS was not reached.

Patients with HCV-positive infection did not have significantly different outcome than those with HCV-negative 


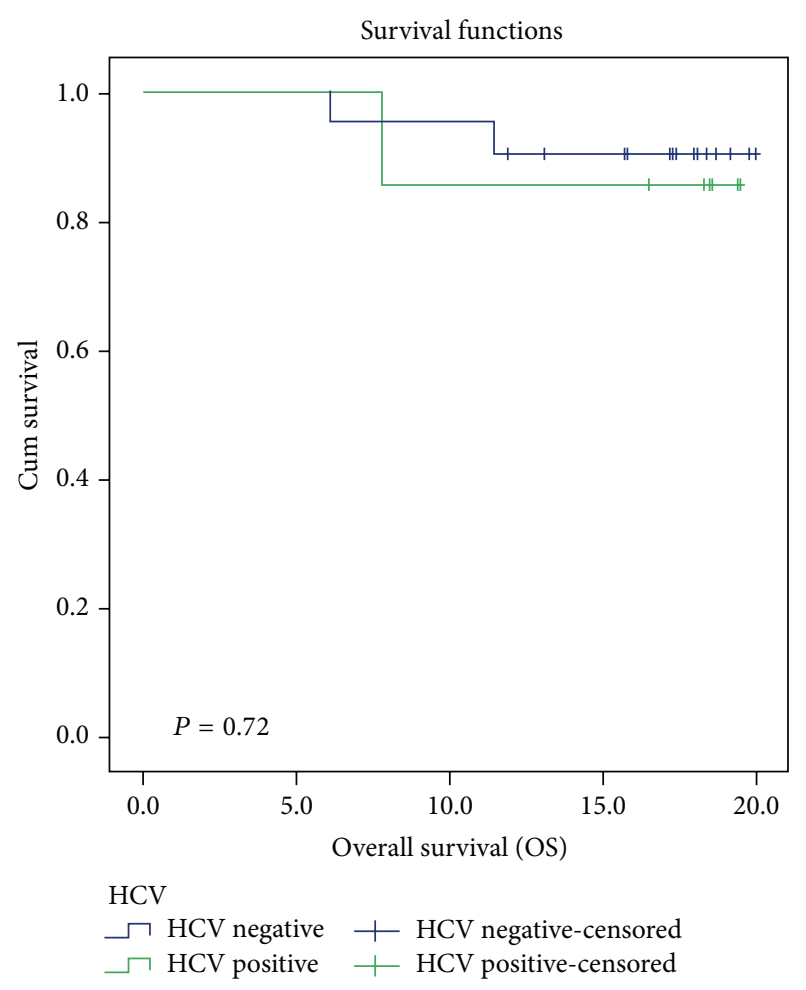

FIGURE 1: Overall survival in relation to HCV infection.

infection, (the 1 -year OS, $85.7 \%$ versus $90.5 \%, P=0.72$ ) and (the 1-year EFS, 74.1\% versus $81 \%, P=0.53$; Figures 1 and 2, resp.).

\section{Hepatic Toxicity}

8.1. Changes in the ALT Levels. As shown in Table 2, the pretreatment transaminase levels were not significantly different between the two groups.

Among the HCV-infected subjects, the incidence of hepatitis flares (defined as an ALT increase $>3$ times the upper limit of normal (grade 2)) was $28.6 \%$ (2/7 patients) versus $4.8 \%$ (1/21 patients) among the HCV-uninfected individuals. However, no patient developed grade 3 or grade 4 elevation of in ALT in both groups $(P=0.15)$.

The onset of enzyme flare in group $B$ started at the 6th cycle of R-CHOP while, in group A, it occurred at the 2nd and 3 rd cycles in the 2 patients who developed enzyme flare (Figure 3). Liver damage did not result in treatment discontinuation in any of them.

8.2. HCV Reactivation. Within the HCV-positive group, the median pretreatment $\mathrm{HCV}$ viral load was $320,400 \mathrm{IU} / \mathrm{mL}$ $(34,500-2,360,000 \mathrm{IU} / \mathrm{mL})$ while the median level after treatment was $970,821 \mathrm{IU} / \mathrm{mL}(79,236-5,420,000 \mathrm{IU} / \mathrm{mL} ; P=$ 0.049).

Viral reactivation $\left(>1 \log _{10}\right.$ increase in the viral load) occurred in $(28.6 \% ; 2 / 7$ patients) in group $\mathrm{A}$ and was associated with grade 2 increase in the ALT level (enzyme flare)

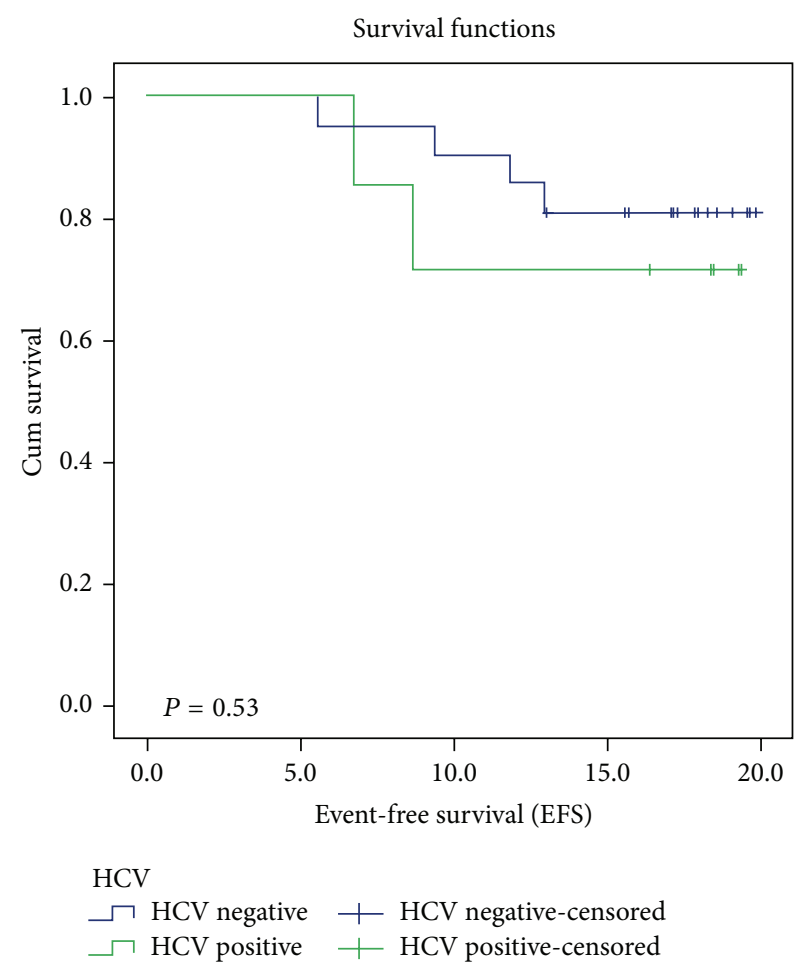

FIgURE 2: Event-free survival in relation to HCV infection.

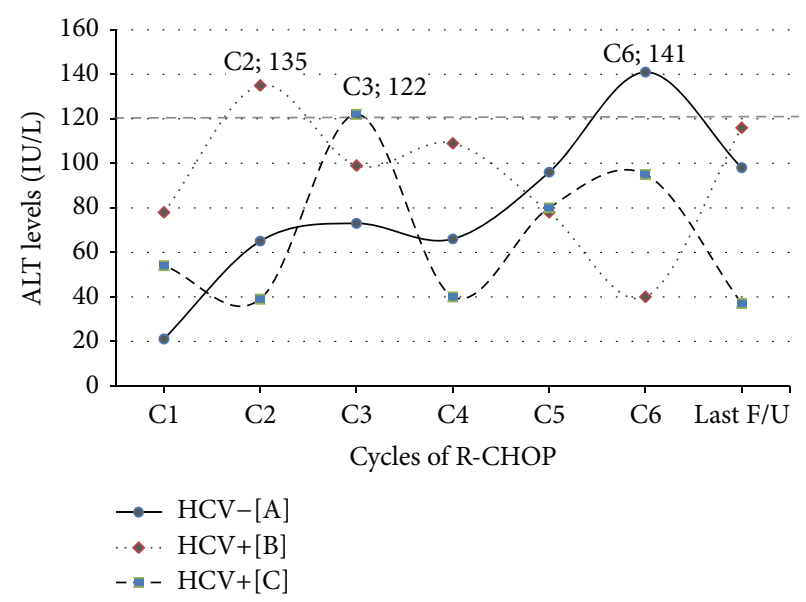

FIGURE 3: Changes in ALT levels in patients who developed enzyme flare.

in one patient of them. However, one patient within the same group developed enzyme flare but without viral reactivation. Thus, there was no significant difference regarding the development of enzyme flare in respect to viral reactivation $(P=$ 0.43 ; Tables 3 and 4).

One of the 2 patients who had viral reactivation HCV load was improved after the treatment had been finished while the other one died without reevaluation of his HCV load. 
TABLE 3: Hepatic toxicity in both groups.

\begin{tabular}{|c|c|c|c|c|}
\hline & Grade & $\begin{array}{l}\text { HCV positive } \\
\text { (group } A ; n=7 \text { ) }\end{array}$ & $\begin{array}{l}\text { HCV negative } \\
\text { (group B; } n=21 \text { ) }\end{array}$ & $P$ value \\
\hline \multirow{3}{*}{ ALT } & G 0 & $1(14.3 \%)$ & $9(42.8 \%)$ & \multirow{3}{*}{0.15} \\
\hline & G 1 & $4(57.1 \%)$ & $11(52.4 \%)$ & \\
\hline & G 2 & $2(28.6 \%)$ & $1(4.8 \%)$ & \\
\hline \multirow{3}{*}{ AST } & G 0 & $1(14.3 \%)$ & $12(57.1 \%)$ & \multirow{3}{*}{0.07} \\
\hline & G 1 & $4(57.1 \%)$ & $8(38.1 \%)$ & \\
\hline & G 2 & $2(28.6 \%)$ & $1(4.8 \%)$ & \\
\hline \multirow{3}{*}{ Bilirubin } & G 0 & $5(71.4 \%)$ & $21(100 \%)$ & \multirow{3}{*}{0.06} \\
\hline & G 1 & $1(14.3 \%)$ & $0(0 \%)$ & \\
\hline & G 2 & $1(14.3 \%)$ & $0(0 \%)$ & \\
\hline \multirow{2}{*}{ INR } & G 0 & $4(57.1 \%)$ & $20(95.2 \%)$ & \multirow{2}{*}{$0.04^{*}$} \\
\hline & G 1 & $3(42.9 \%)$ & $1(4.8 \%)$ & \\
\hline \multirow{3}{*}{ Albumin } & G0 & $6(85.7 \%)$ & $21(100 \%)$ & \multirow{3}{*}{0.25} \\
\hline & G 1 & $0(0 \%)$ & $0(0 \%)$ & \\
\hline & G 2 & $1(14.3 \%)$ & $0(0 \%)$ & \\
\hline \multirow{3}{*}{$\begin{array}{l}\text { Alkaline } \\
\text { phosphatase }\end{array}$} & G0 & $3(42.9 \%)$ & $14(66.7 \%)$ & \multirow{3}{*}{0.21} \\
\hline & G 1 & $3(42.9 \%)$ & $7(33.3 \%)$ & \\
\hline & G 2 & $1(14.3 \%)$ & $0(0 \%)$ & \\
\hline \multirow{3}{*}{$\begin{array}{l}\text { Hepatic } \\
\text { failure }^{\#}\end{array}$} & G 0 & $6(85.7 \%)$ & & \multirow{3}{*}{0.25} \\
\hline & G 3 & $0(0 \%)$ & & \\
\hline & G 4 & $1(14.3 \%)$ & & \\
\hline
\end{tabular}

${ }^{*}$ means significant $(P<0.05)$.

\# means hepatic encephalopathy.

TABLE 4: The relationship between development of enzyme flare and viral reactivation.

\begin{tabular}{lccc}
\hline $\begin{array}{l}\text { Development } \\
\text { of enzyme flare }\end{array}$ & $\begin{array}{c}\text { Viral reactivation } \\
(n=2)\end{array}$ & $\begin{array}{c}\text { No viral reactivation } \\
(n=5)\end{array}$ & $P$ value \\
\hline (i) Yes & $1(50 \%)$ & $1(20 \%)$ & 0.43 \\
(ii) No & $1(50 \%)$ & $4(80 \%)$ & \\
\hline
\end{tabular}

The details of enzyme and viral reactivation in addition to the outcome of HCV-positive patients are shown in Table 5.

8.3. Other Hepatic Toxicities. Grade 1 elevation of INR was significantly higher in group A while no significant differences were found between both groups as regards the changes in the serum albumin, alkaline phosphatase, bilirubin, or development of hepatic encephalopathy (Table 3).

Response rate was significantly higher in patients with normal baseline LDH and very good R-IPI score $(P=0.01$ and 0.001 , resp.).

The 1-year OS rate was significantly higher in responders compared to the nonresponders $(100 \%$ versus $57.5 \%$; $P=$ $0.001)$. However, no significant relation between OS and enzyme flare and delayed scheduled therapy (92\% versus $66.7 \% ; P=0.17$ and $94.4 \%$ versus $81.8 \% ; P=0.29$, resp.).

Moreover, the 1-year EFS rate was significantly worse in those who developed enzyme flare and delayed the scheduled therapy ( $84 \%$ versus $33.3 \%$; $P=0.01$ and $94.1 \%$ versus $54.5 \%$; $P=0.04$, resp.).
Regarding the R-IPI score, the EFS was better in favorable patients as follows: $(100 \%)$ for very good versus $(82.4 \%)$ for good versus (25\%) for poor score; $P=0.006$; also a significant difference was found as regards the OS in relation to the R-IPI $(100 \%, 94.1 \%$, and $50 \%$ for very good, good, and poor scores, resp.; $P=0.025)$.

\section{Discussion}

In our study, we compared clinical outcome, treatment response, and hepatotoxicity in patients with DLBCL who received $\mathrm{R}-\mathrm{CHOP}$ in respect to $\mathrm{HCV}$ infection.

Considerable percentage of patients presented with splenomegaly most probably due to endemicity of schistosomiasis in our geographic region. However, splenic involvement was found only among HCV-positive patients compared to HCV-negative patients (42.9\% versus zero\%; $P=0.01$ ) which is similar to reports of Nishikawa et al. [6], Ennishi et al. [7], Besson et al. [8], and Visco et al. [9] where splenic involvement was $30.2 \%, 18 \%, 46 \%$, and $34 \%$, respectively, in HCV-positive patients. HCV-negative patients showed significantly lower mean hemoglobin level at presentation than HCV-positive patients $(P=0.03)$ unlike results of Nishikawa et al. [6].

In the present study, favorable objective response to R$\mathrm{CHOP}$ was obtained in the HCV group as compared with some previous reports $[6,7,10]$, and there was no significant difference between the HCV group and the HCVnegative group in terms of $\mathrm{CR}$ that comes in agreement with Nishikawa et al. [6] and Ennishi et al. [7], suggesting that the addition of rituximab did not seem to affect the treatment response of DLBCL patients with HCV infection.

In terms of OS and EFS, there were no significant differences between both groups in the present study. Our results suggested that, in DLBCL patients, HCV infection was not a significant risk factor for prognosis in patients receiving RCHOP.

Poor RIPI, enzyme flare, and treatment delay had significant influence on EFS ( $P=0.006,0.011$, and 0.012 , resp.), but regarding OS only poor RIPI had significant effect $(P=$ 0.025).

In the present study, the pretreatment ALT levels were not significantly different regarding HCV infection $(P=$ $0.15)$ which was similar to other previous reports $[6,7]$. However, our results showed no significant difference for development of hepatotoxicity (enzyme flare) as a result of higher basal ALT $(P=0.54)$ which was consistent with Visco et al. [9] who also reported no association between the initial severity of hepatic disease and subsequent liver drug toxicity, regardless of the regimen that was administered, but was inconsistent with $[6,7]$ which reported that hepatotoxicity in HCV-positive DLBCL patients undergoing immunochemotherapy was more likely to occur if pretreatment ALT levels were high. Our results demonstrate a good tolerance to R-CHOP in HCV-infected DLBCL patients; as no significant difference in enzyme flare developed during treatment between both groups this comes in agreement with Nishikawa et al. [6], who reported that enzyme flare was 


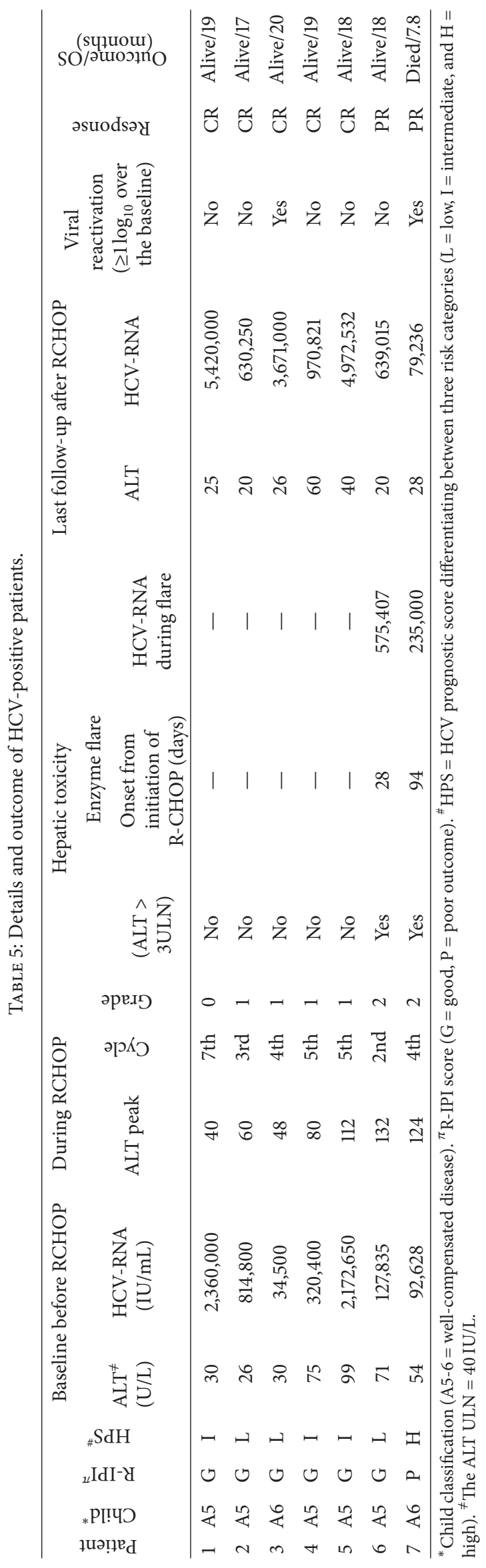


$15.9 \%$ in $\mathrm{HCV}$-negative versus $25 \%$ in $\mathrm{HCV}$-positive; $P=$ 0.28 . On the contrary, Ennishi et al. [7] reported that enzyme flare was significantly higher in HCV-positive patients who received immunochemotherapy.

None of our patients developed grade 3 or grade 4 hepatotoxicity, and none required discontinuation of R-CHOP owing to hepatotoxicity or other causes. However, the 3 patients ( 3 of 28 patients) who developed enzyme flare (grade 2) delayed their scheduled therapy but continued again after normalization of liver enzymes with a median time of delay 10 days (range 7-14 days) and that comes in agreement with results of Nishikawa et al. [6], Nosotti et al. [11], and Marignani et al. [12].

In addition, viral reactivation occurred in $28.6 \%$ of HCVpositive patients (2/7 patients) in our study which was inconsistent with the results of Boyle and Reid [13] who reported that $66.6 \%$ of HCV-positive NHL patients (6/9 patients) developed viral reactivation that could be explained as they did not exclude HIV-positive patients and with Ennishi et al. [14] who reported that an increase of HCV-RNA during immunochemotherapy was observed in 5 out of $6 \mathrm{HCV}$ positive NHL patients (83.3\%); this great variation can be explained by different definitions of viral reactivation.

Interestingly, one of the two patients who developed viral reactivation was shifted to salvage chemotherapy for relapse without any further reactivation while the other one died after 7.8 months of diagnosis when shifted to a salvage therapy due to progression of lymphoma and then developed ascites and hepatic encephalopathy without further HCV load reevaluation.

Our study also reported increased HCV-RNA significantly during R-CHOP $(P=0.049)$ and that comes in concordance with many previous reports [7, 10-12], with no significant relation between viral reactivation and development of enzyme flare $(P=0.43)$ and this comes in agreement with Marignani et al. [12] and Merli et al. [10].

In conclusion, our study results suggested that HCV infection might not influence the clinical course in DLBCL patients who received R-CHOP and also HCV-RNA quantification seems to behave irrespectively of ALT levels and may not be useful for predicting liver toxicity but more studies with larger sample size and longer follow-up are needed.

\section{Conflict of Interests}

The authors declare that there is no conflict of interests regarding the publication of this paper.

\section{Acknowledgment}

This work was done at Department of Medical Oncology, Faculty of Medicine, Zagazig University, Sharkia, Egypt.

\section{References}

[1] A. L. Zignego, C. Giannini, and L. Gragnani, "HCV and lymphoproliferation," Clinical and Developmental Immunology, vol. 2012, Article ID 980942, 8 pages, 2012.
[2] B. Coiffier, E. Lepage, J. Brière et al., "CHOP chemotherapy plus rituximab compared with chop alone in elderly patients with diffuse large-B-cell lymphoma," The New England Journal of Medicine, vol. 346, no. 4, pp. 235-242, 2002.

[3] M. Pfreundschuh, L. Trümper, A. Österborg et al., "CHOP-like chemotherapy plus rituximab versus CHOP-like chemotherapy alone in young patients with good-prognosis diffuse large-Bcell lymphoma: a randomised controlled trial by the MabThera International Trial (MInT) Group," The Lancet Oncology, vol. 7, no. 5, pp. 379-391, 2006.

[4] Y. Tsutsumi, Y. Yamamoto, J. Tanaka, M. Asaka, M. Imamura, and N. Masauzi, "Prevention of hepatitis B virus reactivation under rituximab therapy," Immunotherapy, vol. 1, no. 6, pp. 1053-1061, 2009.

[5] C. A. Heid, J. Stevens, K. J. Livak, and P. M. Williams, "Real time quantitative PCR," Genome Research, vol. 6, no. 10, pp. 986-994, 1996.

[6] H. Nishikawa, M. Tsudo, and Y. Osaki, "Clinical outcome in diffuse large $\mathrm{B}$-cell lymphoma with hepatitis $\mathrm{C}$ virus infection in the rituximab era: a single center experience," Oncology Reports, vol. 28, no. 3, pp. 835-840, 2012.

[7] D. Ennishi, Y. Maeda, N. Niitsu et al., "Hepatic toxicity and prognosis in hepatitis $\mathrm{C}$ virus-infected patients with diffuse large B-cell lymphoma treated with rituximab-containing chemotherapy regimens: a Japanese multicenter analysis," Blood, vol. 116, no. 24, pp. 5119-5125, 2010.

[8] C. Besson, D. Cantoni, E. Lepage et al., "Characteristics and outcome of diffuse large B-cell lymphoma in hepatitis $\mathrm{C}$ viruspositive patients in LNH 93 and LNH 98 groupe detude des lymphomes de l'adulte programs," Journal of Clinical Oncology, vol. 24, no. 6, pp. 953-960, 2006.

[9] C. Visco, L. Arcaini, E. Brusamolino et al., "Distinctive natural history in hepatitis $\mathrm{C}$ virus positive diffuse large B-cell lymphoma: analysis of 156 patients from northern Italy," Annals of Oncology, vol. 17, no. 9, pp. 1434-1440, 2006.

[10] M. Merli, C. Visco, M. Spina et al., "Outcome prediction of diffuse large B-cell lymphomas associated with hepatitis $\mathrm{C}$ virus infection: a study on behalf of the Fondazione Italiana Linfomi," Haematologica, vol. 99, no. 3, pp. 489-496, 2013.

[11] L. Nosotti, M. D’Andrea, A. Pitidis et al., "Hepatitis C virus infection prevalence and liver dysfunction in a cohort of B-cell non-Hodgkin's lymphoma patients treated with immunochemotherapy," Scandinavian Journal of Infectious Diseases, vol. 44, no. 1, pp. 70-73, 2012.

[12] M. Marignani, M. Mangone, M. C. Cox et al., "HCV-positive status and hepatitis flares in patients with B-cell non-Hodgkin's lymphoma treated with rituximab-containing regimens," Digestive and Liver Disease, vol. 43, no. 2, pp. 139-142, 2011.

[13] F. Boyle and E. Reid, "Viral reactivation and clinical hepatitis in patients with hepatitis $\mathrm{C}$ who receive rituximab as part of chemotherapy for treatment of lymphoma: a case series," Journal of Clinical Oncology, vol. 28, supplement, abstract e18559, 2010.

[14] D. Ennishi, Y. Terui, M. Yokoyama et al., "Monitoring serum hepatitis $\mathrm{C}$ virus (HCV) RNA in patients with HCV-infected CD20-positive B-cell lymphoma undergoing rituximab combination chemotherapy," American Journal of Hematology, vol. 83, no. 1, pp. 59-62, 2008. 


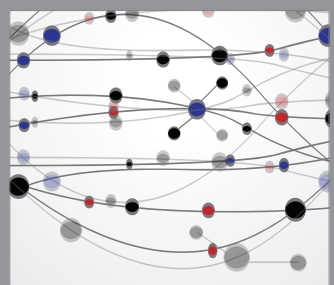

The Scientific World Journal
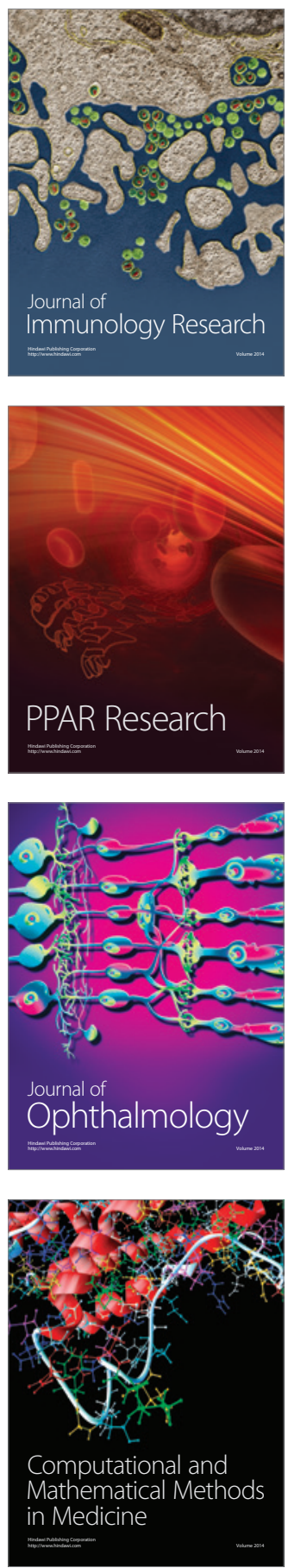

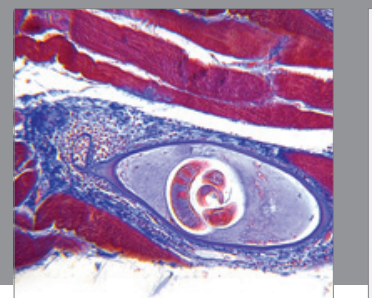

Gastroenterology

Research and Practice
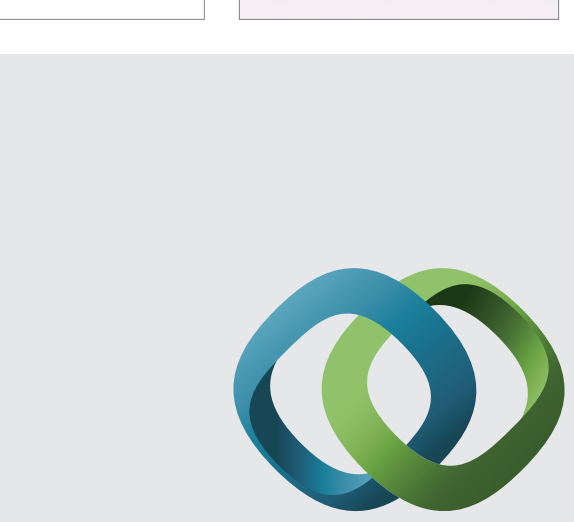

\section{Hindawi}

Submit your manuscripts at

http://www.hindawi.com
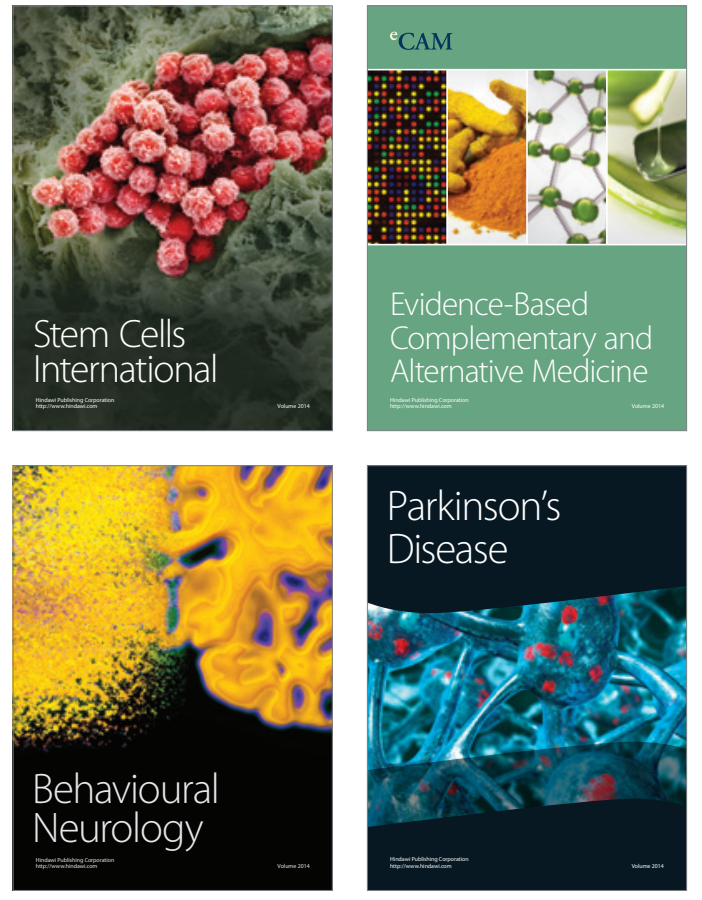
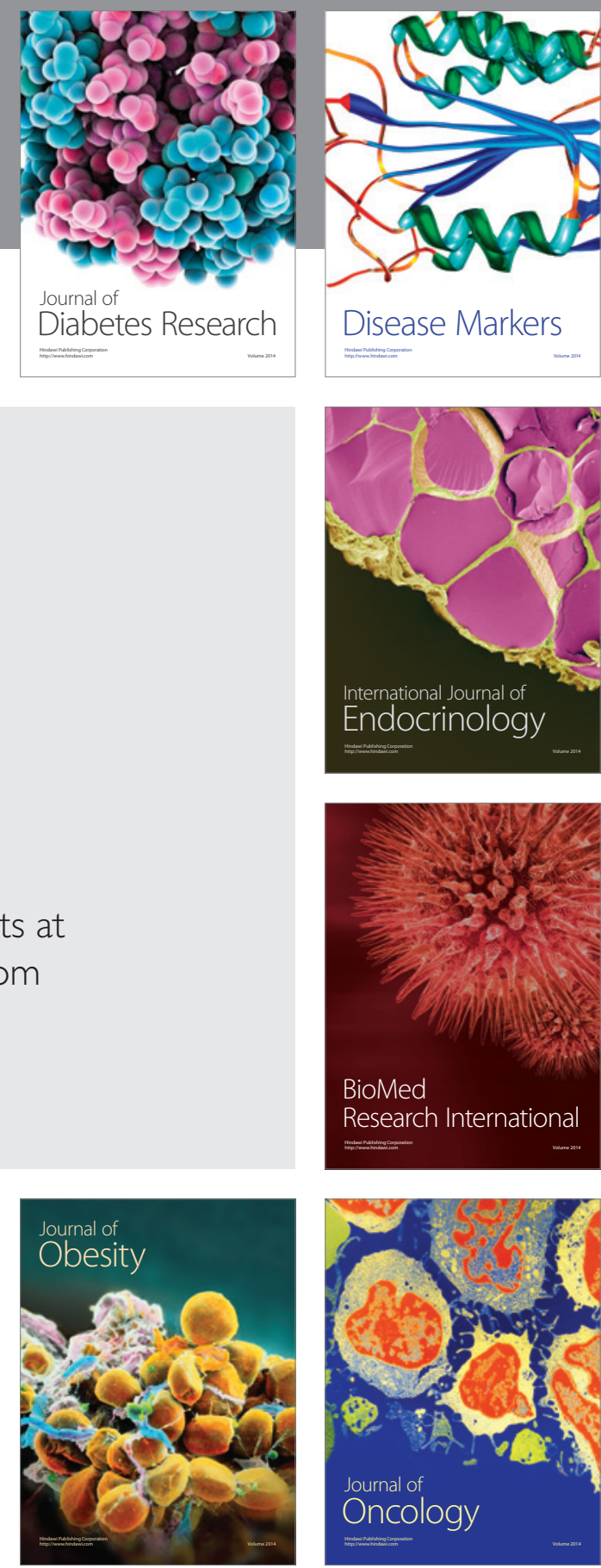

Disease Markers
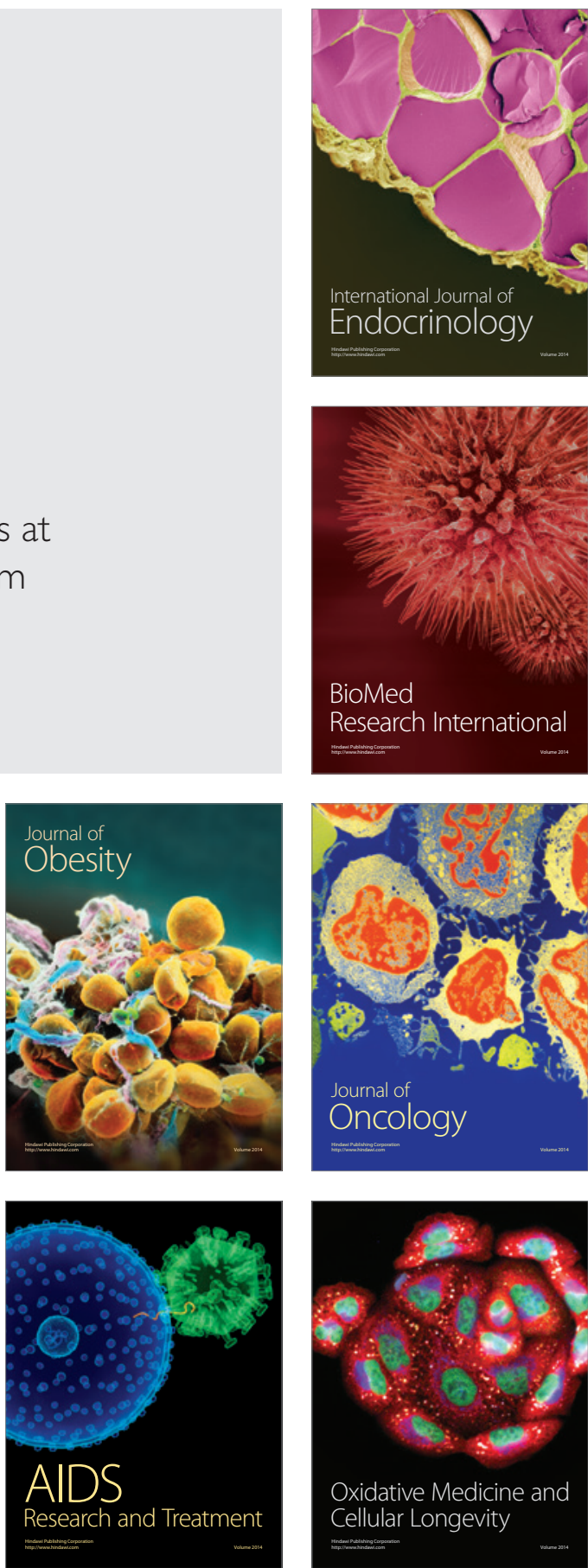